GIBBS, P. E. and N. TARODA (1983): Heterostily in the Cordia alliodora - C. trichotoma complex in Brazil. Revista Brasileira de Botânica 6: 3-10.

Greaves, A. and McCARTER, P. S. (1990): Cordia alliodora: a promising tree for tropical agroforestry. Tropical Forestry Papers 22. Oxford Forestry Institute, Oxford, UK. 37 p.

HERNANDEZ, G. O. R. (1995): Rendimiento y analisis financiero del sistema agroforestal café (Coffea arabica cv Caturra) con poro (Erythrina poeppigiana) bajo diferentes densidades de laurel (Cordia alliodora). Unpublished M. S. Thesis. CATIE, Turrialba, Costa Rica. 70 p.

Hummel, S. (2001): Una especie nativa en plantaciones: Cordia alliodora. OIMT Actualidad Forestal Tropical 9/3. http://www.itto.or.jp/live/Live_Server/128/ tfu.2001.03(18).s.pdf.

Liegel, L. H. and J. W. Stead (1990): Cordia alliodora (Ruiz \& Pav.) Oken. Laurel capá prieto. In: Russel, M., Honkala, B. H. (eds). Silvics of North America: 2. Hardwoods. Agric. Handb. 654. Washington, DC: US. Department of Agriculture, Forest Service: 270-277.

RESENDE, M. D. V. (2002): Genética biométrica e estatística no melhoramento de plantas perenes. Brasília, DF, Embrapa Informação Tecnológica, 975p.

S.A.S. (1989): Institute Inc. SAS Procedures Guide. Version 8 (TSMO). SAS Institute Inc. Cary, N.C., 27513, USA.

Sebbenn, A. M., P. Y. Kageyama and A. C. S. Zanatto (2002): Estimativas de ganhos genéticos na seleção em populações de Cariniana legalis (Mart.) O. Ktze, incorporando informações do sistema misto de reprodução. Revista do Instituto Florestal 14: 65-77.

Sebbenn, A. M. S., A. C. S. Zanatto, M. L. M. Freitas, A. S. SATO and L. C. EtTori (2005): Genetic variation in Araucaria cunninghamii provenances in Luiz AntonioSP, Brazil. Crop Breeding and Applied Biotechnology 4: $1-8$.

SomArRIBA, E. and J. W. Beer (1987): Dimensions, volumes, and growth of Cordia alliodora in agroforestry systems. Forest Ecology and Management 18: 113-126.

StEAD, J. W. (1980): Commonwealth Forestry Institute international provenance trial of Cordia alliodora (R. \& P.) Oken. Eleventh Commonwealth Forestry Conference, Trinidad and Tobago and Jamaica, September, 17p.

Ventura, A., G. Berengut and M. A. M. Victor (1965/1966): Características edafoclimáticas das dependências do Serviço Florestal do Estado de São Paulo. Silvicultura 4: 57-139.

YARED, J. A. G. (1983): Comportamento e variabilidade de procedências de Cordia alliodora (Ruiz \& Pav.) Oken, no planalto do Tapajós - Beltera-PA. Unpublished thesis, Universidade de São Paulo (ESALQ/USP), Piracicaba-SP. 108 p.

Zobel, B. and J. TALBert (1984): Applied forest tree improvement. Copyright by John Wiley \& Sons Inc. New York. 496p.

\title{
Genetic Variation and Climatic Impacts on Survival and Growth of White Spruce in Alberta, Canada
}

\author{
By D. M. RweyongezA ${ }^{1), 2)}$, R.-C. YANG ${ }^{2)}$, N. K. DhiR ${ }^{3)}$, L. K. BARNHARDT ${ }^{3)}$ and C. HANSEN ${ }^{3)}$
}

(Received $15^{\text {th }}$ February 2006)

\begin{abstract}
Because climate has the greatest effect in determining the genetic structure of forest tree species, climatic variables with large effects on growth and survival need to be identified. This would enable proper matching of tree populations to planting sites in the present and future climates. We analysed 24-year survival (S24), height (H24) and diameter (D24) from a series of white spruce provenance trials with 46 populations and 8 test sites in Alberta, Canada. We determined: (1) the amount and pattern of genetic variation, (2) the response of populations to climatic transfer and (3) the potential effects of climate change (2030-2039) on H24 and S24 of the

1) Corresponding author: Deogratias M. Rweyongeza. Tel. 780422-5436, Fax: 780-427-0084. Email: drweyong@ualberta.ca

2) Department of Agricultural, Food and Nutritional Science University of Alberta, Edmonton, AB, Canada, T6G 2P5.

$\left.{ }^{3}\right)$ Alberta Tree Improvement and Seed Centre, Alberta Sustainable Resource Development, Smoky Lake, AB, Canada, T0A $3 \mathrm{C} 0$.
\end{abstract}

species in Alberta. We found that: (1) using the intraclass correlation, the between-population genetic variance was $10.6 \%(\mathrm{H} 24)$ and $6.6 \%$ (D24) of the betweenpopulation phenotypic variance across sites, (2) three climatic white spruce regions exist in Alberta within which variation in growth potential is strongly clinal, (3) the annual moisture index (AMI) expressed as a ratio of degree days above $5^{\circ} \mathrm{C}$ (GDD) and mean annual precipitation (MAP) was the major determinant of survival and growth at the test sites, (4) we found that at the level of AMI predicted for the 2030-2039 period, survival and growth would decline substantially in the continental part (northern and central) of Alberta where drought already exists. However, during the same period, survival and growth would increase substantially in the foothills and Rocky Mountains region where growth is currently limited by low GDD due to a short growing season.

Key words: climate change, moisture index, Picea glauca, provenance trial, response function. 


\section{Introduction}

Climate is a major determinant of the spatial genetic differentiation of forest tree species. Studies have shown that in the Northern Hemisphere, growth potential declines northward (e.g., LANGLET, 1959; KRUTZSCH, 1992; RudolPh and Yeatman, 1982; XIE and YING, 1995) and from low to high elevation (REHFELDT, 1989; KLENSCHMIT and BASTIEN, 1992; BONGARTEN and HANOVER, 1986) partly in response to variation in temperature (MATYAS and YEATMAN, 1992). In addition, provenance trials have shown that climate determine survival and growth when tree populations are planted on a range of field environments (e.g., MatYas and YEATMAN, 1992; REHFELDT et al., 1999, 2001, 2002). Therefore, the knowledge of the climatic factors affecting the genetic differentiation of tree species is essential for matching populations to planting sites and adapting to the expected climate change.

In provenance trials, tree populations are planted on a range of sites with different climates and ecology. Consequently, these trials provide the best material for simulating climate change and its effects on survival and growth of individual populations (MATYAS, 1994, 1996; Stettler and BradshaW, 1994). Provenance trials have been used in jack pine (Pinus banksiana Lamb.) (Matyas and Yeatman, 1992), lodgepole pine (Pinus contorta Dougl.) (REHFELDT et al., 1999, 2001), Scotch pine (Pinus sylvestris L.) (REHFELDT et al., 2002), white spruce (Picea glauca (Moench.) Voss) (ANDALO et al., 2005), Loblolly pine (Pinus taeda L.) and Norway spruce (Picea abies (L.) Kharst) (SchmidtLING, 1994) to model the response of species and populations to climatic transfer and predict their survival and growth in a changed climate.

Recent research results have shown that tree populations differ in their climatic optima and that in a changing climate, populations and regions of the species geographic ranges could be affected differently (e. g., REHFELDT et al., 1999, 2001, 2002). In the present work, we examine the level of population differentiation of white spruce in Alberta, the role of climate in this population structure, the population-specific response to climatic transfer and how the observed level of population climatic sensitivity could affect survival and growth of white spruce in a changing climate.

White spruce is widely distributed across Canada, northeastern USA and Alaska (NIENSTAEDT and ZASADA, 1990). It occurs throughout Alberta, except in the prairies, subalpine and alpine regions. In the foothills and Rocky Mountains of western Alberta, white spruce generally occurs below 1370 metres in the south (OGILVE and VON RUDOLFF, 1968) and 1220 metres in the north (ACHUFF and LA RoI, 1977). This boundary is variable due to the heterogeneity of foothills environments and a distribution related to climate and clinal introgression with Engelmann spruce (Picea engelmannii Parry ex Engelm.), which occurs at higher elevations (LA RoI and Dugle, 1968; ACHUFF and LA RoI, 1977; RAJORA and DANCIK, 2000). In the Rocky Mountains, the upper boundary of white spruce and lower boundary of Engelmann spruce are intertwined. As a result, both pure white spruce and hybrid populations have been identi- fied at elevations as high as 1450 and 1524 metres (LA RoI and Dugle, 1968; RAJORA and DANCIK, 2000). In southern Alberta, the limit of white spruce distribution occurs at the woodland - prairie transition where drought is limiting to tree distribution, mean annual precipitation is low (380-510 millimetres) and mean July temperature maxima are greater than $24^{\circ} \mathrm{C}$ (NIENSTAEDT and ZASADA, 1990).

Although white spruce is the most important forest tree species in Alberta comprising of $45.9 \%$ by volume of the coniferous species and $27.9 \%$ of coniferous and deciduous species combined (AFLW, 1985), its genetic variation has been studied extensively only in eastern Canada and northeastern USA. Therefore, this study addresses the following questions: (1) How much population differentiation is there for white spruce in Alberta? (2) To what extent is population differentiation of white spruce in Alberta determined by regional climate? (3) What planting site climate variables affect survival and growth of white spruce in Alberta? (4) What are the potential impacts of the expected climate change on future survival and growth of white spruce in Alberta? Throughout the article, the term population refers to provenance or location where seeds were collected.

\section{Materials and Methods \\ Experimental Procedures}

Between 1959 and 1976, the Alberta Forest Service collected white spruce seedlots from 46 natural stands distributed across Alberta. These bulk collections were made primarily for operational reforestation and sampled a large number of trees. At the beginning of the Alberta tree improvement programme in 1975, the archived seedlots from these collections were used to initiate a series of provenance trials across Alberta. The populations covered in this article are described in Table 1 and Figure 1. All populations from the sympatric zone of white and Engelmann spruces were treated as white spruce.

Field trials were established with 4-year old seedlings between 1980 and 1983 at 12 sites, each containing 26-30 populations. These included a set of 21 populations that were planted at all 12 sites and 5-9 other populations that were selectively allocated to specific test sites as local controls. Four of the test sites exhibited poor survival and could not be continued beyond age 15 years. Therefore, the present article covers performance on 8 sites that exist today. These sites are described in Table 1 and their approximate locations in Alberta appear in Figure 1.

The field layout was a randomised complete block design with 5 replications and 9-tree row plots at $2.5 \times 2.5$ metre spacing. A border row was planted around each trial to eliminate the edge effect. Trees were maintained free-to-grow by hand weeding and brushing at one to three-year intervals. The present article covers survival (S24), total height (H24) and diameter at breast height (D24) at the age of 24 years.

\section{Climate Data and Choice of Variables}

The 1961-1990 climate data for population and test site locations were derived from the Alberta Climate 
Table 1. - Locations and climatic (1961-1990) description for populations and test sites in the Alberta white spruce provenance trials.

\begin{tabular}{|c|c|c|c|c|c|c|c|c|c|c|c|c|}
\hline$\overline{\mathrm{ID}}$ & Location & $\begin{array}{l}\text { LAT. } \\
\left({ }^{\circ} \mathrm{N}\right)\end{array}$ & $\begin{array}{l}\text { LON. } \\
\left({ }^{\circ} \mathrm{W}\right)\end{array}$ & $\begin{array}{l}\text { ELE. } \\
(\mathrm{m})\end{array}$ & $\begin{array}{l}\text { MAT } \\
\left({ }^{\circ} \mathrm{C}\right)\end{array}$ & $\begin{array}{l}\text { TCM } \\
\left({ }^{\circ} \mathrm{C}\right)\end{array}$ & NDD & $\begin{array}{r}\text { TWM } \\
\left({ }^{\circ} \mathrm{C}\right)\end{array}$ & GDD & $\begin{array}{c}\mathrm{CI} \\
\left({ }^{\circ} \mathrm{C}\right)\end{array}$ & $\begin{array}{l}\text { MAP } \\
(\mathrm{mm})\end{array}$ & AMI \\
\hline \multicolumn{13}{|c|}{ Populations } \\
\hline $2+$ & Footner Lake & $58^{\circ} 44^{\prime}$ & $117^{\circ} 15^{\prime}$ & 335 & -1.6 & -21.9 & 2668 & 16.0 & 1190 & 37.9 & 408 & 2.9 \\
\hline 3 & Footner Lake & $57^{\circ} 55^{\prime}$ & $117^{\circ} 55^{\prime}$ & 305 & -0.3 & -20.8 & 2371 & 16.4 & 1303 & 37.2 & 401 & 3.2 \\
\hline $4+$ & Footner Lake & $57^{\circ} 55^{\prime}$ & $115^{\circ} 30^{\prime}$ & 360 & -0.4 & -20.9 & 2353 & 16.3 & 1275 & 37.2 & 428 & 3.0 \\
\hline 5 & Footner Lake & $58^{\circ} 33^{\prime}$ & $114^{\circ} 14^{\prime}$ & 235 & -1.0 & -21.9 & 2502 & 16.3 & 1239 & 38.2 & 370 & 3.3 \\
\hline $6+$ & Athabasca & $58^{\circ} 44^{\prime}$ & $111^{\circ} 15^{\prime}$ & 235 & -1.7 & -23.9 & 2759 & 16.9 & 1242 & 40.8 & 386 & 3.2 \\
\hline 7 & Athabasca & $58^{\circ} 12^{\prime}$ & $111^{\circ} 23^{\prime}$ & 229 & -0.9 & -22.5 & 2554 & 17.3 & 1330 & 39.8 & 417 & 3.2 \\
\hline $8+$ & Athabasca & $57^{\circ} 08^{\prime}$ & $111^{\circ} 38^{\prime}$ & 274 & -0.2 & -21.1 & 2351 & 16.9 & 1340 & 38.0 & 439 & 3.1 \\
\hline 9 & Athabasca & $56^{\circ} 38^{\prime}$ & $111^{\circ} 10^{\prime}$ & 370 & 0.2 & -19.7 & 2203 & 16.6 & 1320 & 36.3 & 473 & 2.8 \\
\hline $10+$ & Athabasca & $59^{\circ} 53^{\prime}$ & $111^{\circ} 43^{\prime}$ & 183 & -2.6 & -25.2 & 2984 & 16.7 & 1174 & 41.9 & 331 & 3.5 \\
\hline 11 & Lac La Biche & $54^{\circ} 22^{\prime}$ & $110^{\circ} 45^{\prime}$ & 550 & 0.8 & -18.4 & 2035 & 16.4 & 1351 & 34.8 & 418 & 3.2 \\
\hline $12+$ & Lac La Biche & $54^{\circ} 38^{\prime}$ & $110^{\circ} 13^{\prime}$ & 610 & 0.6 & -18.0 & 2039 & 16.2 & 1300 & 34.2 & 462 & 2.8 \\
\hline 13 & Lac La Biche & $54^{\circ} 58^{\prime}$ & $112^{\circ} 10^{\prime}$ & 551 & 1.3 & -16.8 & 1835 & 16.1 & 1310 & 32.9 & 503 & 2.6 \\
\hline 14 & Lac La Biche & $55^{\circ} 13^{\prime}$ & $113^{\circ} 12^{\prime}$ & 610 & 1.0 & -17.4 & 1889 & 15.9 & 1261 & 33.3 & 482 & 2.6 \\
\hline $15+$ & Slave Lake & $56^{\circ} 38^{\prime}$ & $114^{\circ} 35^{\prime}$ & 731 & -0.1 & -17.5 & 2054 & 14.8 & 1083 & 32.3 & 439 & 2.0 \\
\hline $16+$ & Slave Lake & $54^{\circ} 48^{\prime}$ & $116^{\circ} 59^{\prime}$ & 731 & 2.5 & -12.7 & 1432 & 15.6 & 1294 & 28.3 & 553 & 2.3 \\
\hline $17+$ & Slave Lake & $55^{\circ} 14^{\prime}$ & $114^{\circ} 46^{\prime}$ & 610 & 1.5 & -15.0 & 1701 & 15.7 & 1259 & 30.7 & 520 & 2.4 \\
\hline 18 & Slave Lake & $54^{\circ} 32^{\prime}$ & $114^{\circ} 05^{\prime}$ & 640 & 1.6 & -15.5 & 1725 & 15.9 & 1291 & 31.4 & 509 & 2.5 \\
\hline 19 & Slave Lake & $55^{\circ} 29^{\prime}$ & $116^{\circ} 05^{\prime}$ & 610 & 1.4 & -16.4 & 1794 & 15.8 & 1287 & 32.2 & 481 & 2.7 \\
\hline 20 & Slave Lake & $55^{\circ} 46^{\prime}$ & $113^{\circ} 18^{\prime}$ & 579 & 0.8 & -17.7 & 1946 & 16.0 & 1263 & 33.7 & 509 & 2.5 \\
\hline $21+$ & Peace River & $57^{\circ} 36^{\prime}$ & $117^{\circ} 31^{\prime}$ & 460 & -0.5 & -20.6 & 2340 & 15.8 & 1223 & 36.4 & 443 & 2.8 \\
\hline 22 & Peace River & $56^{\circ} 59^{\prime}$ & $117^{\circ} 50^{\prime}$ & 610 & -0.3 & -19.3 & 2230 & 15.4 & 1174 & 34.7 & 445 & 2.6 \\
\hline $23+$ & Peace River & $56^{\circ} 34^{\prime}$ & $119^{\circ} 40^{\prime}$ & 762 & -0.2 & -18.0 & 2101 & 14.7 & 1086 & 32.7 & 454 & 2.4 \\
\hline 24 & Peace River & $56^{\circ} 28^{\prime}$ & $118^{\circ} 05^{\prime}$ & 823 & -0.1 & -17.4 & 2073 & 14.8 & 1114 & 32.2 & 480 & 2.3 \\
\hline 26 & Grande Prairie & $55^{\circ} 35^{\prime}$ & $119^{\circ} 35^{\prime}$ & 838 & 0.8 & -15.0 & 1771 & 14.5 & 1104 & 29.5 & 522 & 2.1 \\
\hline $27+$ & Grande Prairie & $55^{\circ} 35^{\prime}$ & $118^{\circ} 18^{\prime}$ & 640 & 1.6 & -15.7 & 1747 & 15.8 & 1320 & 31.5 & 483 & 2.7 \\
\hline 28 & Grande Prairie & $55^{\circ} 08^{\prime}$ & $117^{\circ} 17^{\prime}$ & 667 & 2.4 & -13.9 & 1528 & 16.1 & 1365 & 30.0 & 490 & 2.8 \\
\hline $29+$ & Grande Prairie & $54^{\circ} 27^{\prime}$ & $117^{\circ} 38^{\prime}$ & 940 & 1.8 & -13.9 & 1474 & 14.5 & 1112 & 27.4 & 611 & 1.8 \\
\hline 30 & Grande Prairie & $54^{\circ} 38^{\prime}$ & $117^{\circ} 57^{\prime}$ & 990 & 1.6 & -12.9 & 1507 & 14.3 & 1088 & 27.2 & 614 & 1.8 \\
\hline $31+$ & Edson & $53^{\circ} 46^{\prime}$ & $118^{\circ} 48^{\prime}$ & 1402 & 0.7 & -11.7 & 1462 & 12.1 & 773 & 23.8 & 627 & 1.2 \\
\hline $32+$ & Edson & $53^{\circ} 14^{\prime}$ & $117^{\circ} 28^{\prime}$ & 1342 & 1.5 & -11.4 & 1372 & 13.3 & 932 & 24.7 & 601 & 1.6 \\
\hline 34 & Edson & $53^{\circ} 19^{\prime}$ & $117^{\circ} 51^{\prime}$ & 1067 & 2.4 & -10.7 & 1232 & 14.2 & 1079 & 24.9 & 566 & 1.9 \\
\hline 35 & Whitecourt & $53^{\circ} 39^{\prime}$ & $115^{\circ} 42^{\prime}$ & 838 & 1.7 & -13.7 & 1547 & 14.8 & 1166 & 28.5 & 568 & 2.1 \\
\hline 36 & Whitecourt & $54^{\circ} 16^{\prime}$ & $115^{\circ} 18^{\prime}$ & 762 & 1.8 & -13.9 & 1574 & 15.3 & 1219 & 29.2 & 535 & 2.3 \\
\hline $37+$ & Whitecourt & $54^{\circ} 11^{\prime}$ & $116^{\circ} 37^{\prime}$ & 945 & 2.3 & -11.1 & 1341 & 14.8 & 1159 & 25.9 & 591 & 2.0 \\
\hline 38 & Whitecourt & $54^{\circ} 22^{\prime}$ & $114^{\circ} 40^{\prime}$ & 610 & 1.9 & -11.1 & 1647 & 16.0 & 1327 & 31.0 & 480 & 2.8 \\
\hline 39 & Roc/Clearwater & $52^{\circ} 33^{\prime}$ & $115^{\circ} 30^{\prime}$ & 1067 & 2.4 & -15.0 & 1304 & 14.8 & 1153 & 26.2 & 610 & 1.9 \\
\hline $40+$ & Roc/Clearwater & $52^{\circ} 10^{\prime}$ & $115^{\circ} 28^{\prime}$ & 1341 & 1.4 & -11.5 & 1380 & 13.2 & 911 & 24.7 & 620 & 1.5 \\
\hline 41 & Roc/Clearwater & $52^{\circ} 00^{\prime}$ & $115^{\circ} 15^{\prime}$ & 1280 & 1.8 & -11.1 & 1294 & 13.3 & 947 & 24.4 & 624 & 1.5 \\
\hline 42 & Roc/Clearwater & $52^{\circ} 43^{\prime}$ & $115^{\circ} 25^{\prime}$ & 1036 & 2.5 & -11.6 & 1328 & 15.1 & 1205 & 26.7 & 614 & 2.0 \\
\hline 43 & Roc/Clearwater & $52^{\circ} 55^{\prime}$ & $115^{\circ} 47^{\prime}$ & 1067 & 2.2 & -11.8 & 1367 & 14.8 & 1161 & 26.6 & 618 & 1.9 \\
\hline 45 & Bow/Crow & $50^{\circ} 48^{\prime}$ & $114^{\circ} 36^{\prime}$ & 1463 & 2.0 & -9.8 & 1201 & 13.2 & 921 & 23.0 & 599 & 1.5 \\
\hline $46+$ & Bow/Crow & $51^{\circ} 24^{\prime}$ & $115^{\circ} 13^{\prime}$ & 1600 & 0.8 & -11.5 & 1466 & 12.5 & 807 & 24.0 & 593 & 1.4 \\
\hline 47 & Bow/Crow & $50^{\circ} 05^{\prime}$ & $114^{\circ} 30^{\prime}$ & 1830 & 0.8 & -10.3 & 1407 & 12.5 & 780 & 22.8 & 689 & 1.1 \\
\hline $48+$ & Bow/Crow & $49^{\circ} 39^{\prime}$ & $114^{\circ} 37^{\prime}$ & 1585 & 2.2 & -9.2 & 1168 & 13.6 & 943 & 22.8 & 756 & 1.2 \\
\hline $446+$ & Cypress Hills & $49^{\circ} 38^{\prime}$ & $110^{\circ} 14^{\prime}$ & 1310 & 2.4 & -11.7 & 1375 & 15.7 & 1243 & 27.4 & 484 & 2.6 \\
\hline $784+$ & Footner Lake & $59^{\circ} 32^{\prime}$ & $117^{\circ} 13^{\prime}$ & 305 & -2.3 & -23.6 & 2874 & 15.9 & 1171 & 39.5 & 382 & 3.1 \\
\hline \multicolumn{13}{|c|}{ Test Sites } \\
\hline $\mathrm{B}$ & Hay River & $59^{\circ} 08^{\prime}$ & $117^{\circ} 34^{\prime}$ & 370 & -2.3 & -23.1 & 2862 & 15.7 & 1137 & 38.8 & 410 & 2.8 \\
\hline $\mathrm{C}$ & Zeidler Mills & $55^{\circ} 33^{\prime}$ & $114^{\circ} 50^{\prime}$ & 670 & 1.2 & -15.5 & 1765 & 15.4 & 1210 & 30.9 & 551 & 2.2 \\
\hline $\mathrm{D}$ & Sexsmith & $55^{\circ} 31^{\prime}$ & $118^{\circ} 30^{\prime}$ & 805 & 1.2 & -14.9 & 1733 & 15.1 & 1199 & 30.0 & 509 & 2.4 \\
\hline $\mathrm{E}$ & Swartz Creek & $53^{\circ} 23^{\prime}$ & $116^{\circ} 30^{\prime}$ & 990 & 2.0 & -11.6 & 1380 & 14.5 & 1123 & 26.1 & 580 & 1.9 \\
\hline F & Prairie Creek & $52^{\circ} 15^{\prime}$ & $115^{\circ} 21^{\prime}$ & 1220 & 1.6 & -11.7 & 1376 & 13.5 & 965 & 25.2 & 625 & 1.5 \\
\hline G & Chinchaga & $57^{\circ} 50^{\prime}$ & $118^{\circ} 12^{\prime}$ & 470 & -0.8 & -20.8 & 2396 & 15.7 & 1188 & 36.5 & 448 & 2.7 \\
\hline $\mathrm{H}$ & Calling Lake & $55^{\circ} 17^{\prime}$ & $113^{\circ} 09^{\prime}$ & 625 & 0.9 & -17.5 & 1901 & 15.9 & 1254 & 33.4 & 488 & 2.6 \\
\hline $\mathrm{J}$ & Hanginstone & $56^{\circ} 23^{\prime}$ & $111^{\circ} 26^{\prime}$ & 540 & 0.2 & -18.8 & 2112 & 16.1 & 1251 & 34.8 & 534 & 2.3 \\
\hline
\end{tabular}

MAT - mean annual temperature; TCM - mean temperature for coldest month; TWM -mean temperature for the warmest month; NDD degree days below $5{ }^{\circ} \mathrm{C}$; GDD - degree days above $5{ }^{\circ} \mathrm{C}$; CI - continentality index (TWM minus TCM); MAP - mean annual precipitation, AMI - annual moisture index (GDD $\div$ MAP); LAT-latitude; LON - longitude; ELE - elevation + -populations planted on all sites.

Model (ACM I) as described by AlberTA EnvironmenT (2005). Future climate data were derived from ACM II (Alberta EnVIRONMENT, 2004). The future climate scenario adopted in the present study corresponds closely to the HadCM3 climate change scenario for Alberta described by BARROW and YU (2005). This scenario represents a moderate change in temperature and precipi- tation. The future climate period adopted in this article is the year 2030-2039.

The climate variables used for biological analyses were chosen to cover a range of climatic conditions in terms of precipitation, winter and growing season temperatures, temperatures-moisture relationships and their relationship with survival and annual growth cycle 


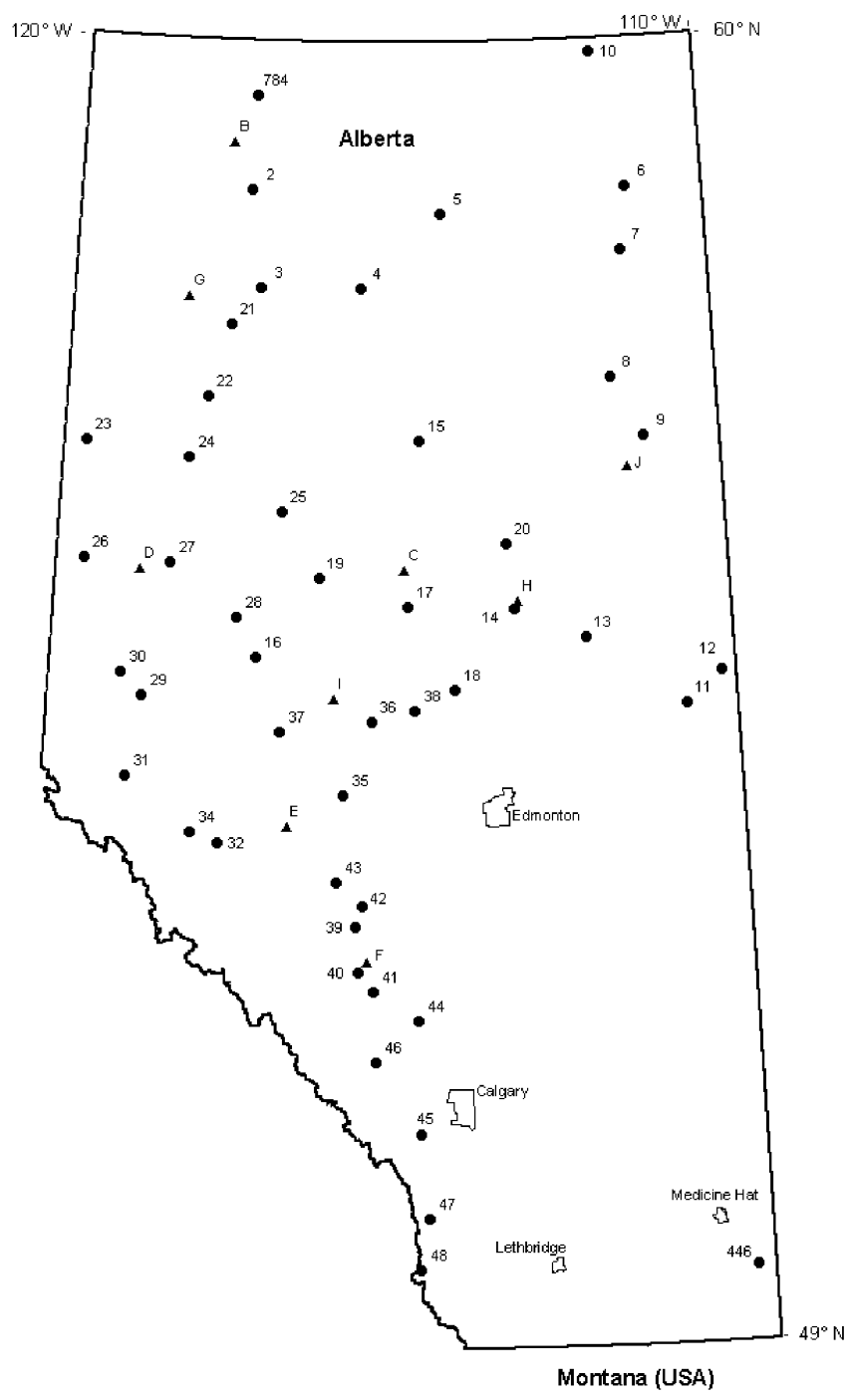

Figure 1. - White spruce populations $(\bullet)$ and test site $(\Delta)$ locations in Alberta. Numbers and capital letters represent population and test site ID, respectively.

of conifers. Because most of the climate variables were derived from each other and were therefore highly intercorrelated, an attempt was made to reduce these variables into few biologically interpretable ones. To do this, the Pearson's correlation coefficients were calculated from the climate of population and test site locations. These correlations were then used to select one or two climate variables that best represent a particular season of the year. The selected variables were mean annual temperature (MAT), degree days below $0^{\circ} \mathrm{C}$ (NDD), mean temperature for the coldest month (TCM), mean temperature for the warmest month (TWM), degree days above $5{ }^{\circ} \mathrm{C}$ (GDD), the continentality index (CI) expressed as temperature difference between the warmest and coldest months (CI = TWM minus TCM), mean annual precipitation (MAP) and the annual moisture index (AMI) expressed as GDD $\div$ MAP.

AMI was chosen to represent a balance between heat and moisture during the growing season. High values of AMI represent dry conditions due high heat (GDD) relative to moisture (MAP) and, therefore, a potential for drought. High GDD could result from either hot sum- mers or warm and long summers. Likewise, low values of AMI represent cool conditions relative to the available moisture, which are characteristic of regions with short growing seasons. These selected variables describe populations and test site locations in terms of their average annual temperature and moisture, average and extreme winter temperatures, average and extreme summer temperatures, and heat-moisture relationship during the growing season. In addition, studies by REHFELDT et al. (1999, 2001, 2002), Matyas and Yeatman (1992) and our unpublished studies on the major Alberta conifers have shown that these are the main climate variables controlling growth and survival in northern conifers.

\section{Analysis of Genetic Variation}

Before performing the analysis of variance (ANOVA), data for H24 and D24 were examined and found to conform to the homogeneity of variance and normal distribution assumptions. Single-site ANOVA was performed as described in the following model:

$$
Y_{i j n}=\mu+R_{i}+P_{j}+R P_{i j}+E_{i j n}
$$

where $\mathrm{Y}=$ response $(\mathrm{H} 24$ or $\mathrm{D} 24), \mu=$ site mean; $R_{i}, P_{j}$, $R P_{i j}$ and $E_{i j n}$ are effect due to ith replication, $j$ th population, experimental error and residual for $n t h$ tree in $j t h$ population in ith replication, respectively. Except $\mu$, all effects on the right side of equation 1 were considered random with zero expectation and variances $\sigma^{2} r_{s s}$ (replication), $\sigma^{2} p_{s s}$ (population), $\sigma_{r p_{s s}}^{2}$ (experimental error) and $\sigma^{2} e_{s s}$ (residual). Likewise, the combined-site ANOVA were performed as described in the following model:

$$
Y_{k i j n}=\mu+S_{k}+R_{i(k)}+P_{j}+S P_{k j}+R P_{i j(k)}+E_{k i m n}
$$

where, $\mathrm{Y}=$ response (H24 or D24), $\mu$ = general mean; $S_{k}$, $R_{i(k)}, S P_{k j}, R P_{i j(k)}$ and $E_{k i j n}$ are effect due to $k t h$ site, ith replication-within $k t h$ site, interaction due to $k t h$ site and jth population, interaction due the ith replicationwithin $k t h$ site and $j t h$ population, and residual for $n t h$ tree in $j t h$ population in ith replication at $k t h$ test site. Except $\mu$, all effects on the right side of equation 2 were considered random with zero expectation and variances $\sigma_{s}^{2}$, (site), $\sigma_{r(s)}^{2}$ (replication-within site), $\sigma^{2} p_{a c}$ (population), $\sigma_{s p}^{2}$ (site $\mathrm{x}$ population interaction), $\sigma_{r p(s)}^{2}$ (replication-within site $\mathrm{x}$ population interaction) and $\sigma^{2} e_{a c}$ (residual). SAS PROC MIXED (SAS InsT., 2004) was used to obtain restricted maximum likelihood (REML) estimates of variance components and to test if these variance components were significantly different from zero. This test used the Wald Z test available in PROC MIXED. All single-site analyses used all populations (26-30) that were planted on specific sites, whereas combined-site analyses used only the 21 populations that were common to all sites.

The amount of genetic variation was estimated using an intraclass correlation, which is the ratio of the between-population genetic variance component to the between-population phenotypic variance component expressed as follows:

$$
\rho_{s s}=\frac{\sigma_{p_{s s}}^{2}}{\sigma_{e_{s s}}^{2}+\sigma_{r p}^{2}+\sigma_{p_{s s}}^{2}}
$$




$$
\rho_{a c}=\frac{\sigma_{p_{a c}}^{2}}{\sigma_{e_{a c}}^{2}+\sigma_{r p(s)}^{2}+\sigma_{s p}^{2}+\sigma_{p_{a c}}^{2}},
$$

where all variance components are as already defined. The subscripts $s s$ and $a c$ are used to identify single site and combined-site statistics where the two cannot be distinguished from the primary notations.

Preliminary stepwise regression analyses indicated that H24 and D24 were significantly $(P \leq 0.05)$ related to latitude, longitude and elevation at a place of seed origin $\left(R^{2}=0.37-0.86\right)$. However, it is generally accepted that, because geographic transfer of seeds involve climatic transfer, growth and survival tend to be related to seed source geography by their relationship with seed source climate (MATYAS, 1994, 1996). Therefore, a principal component analysis (PCA) was performed using MAT, TCM, NDD, TWM, GDD, CI and MAP to examine the climatic grouping of white spruce populations in Alberta and relate this to survival and growth potential of these populations. This PCA analysis used PROC PRINCOMP (SAS INST., 2004).

\section{Analysis of Population Response to Climatic Transfer}

Although the trial at site $\mathrm{C}$ occupies one of the best sites climatically, it exhibited the lowest H24 and D24. Because this trials was established on an abandoned sawmill landing site, it has a great potential for soil compaction, which alters soil-water-air relationships causing tree mortality and poor growth (KozLOwSKI, 1999). Although compacted soils may provide a special type of environment for studying genetic variation, growth and survival on these soils cannot be used for modelling population response to climatic transfer, where climate not soil characteristics is considered the main cause of the observed performance. Therefore, site $\mathrm{C}$ was excluded from the fitted climatic response functions. In addition, because H24 and D24 showed similar response to climatic transfer, only $\mathrm{H} 24$ is used in this paper to illustrate the effect of climate change on tree growth.

Preliminary analysis indicated that S24 and H24 were the lowest at site B and F, which are on the opposite side of the moisture and temperature continuum for most of the selected climatic variables. Therefore, a second degree polynomial regression was considered appropriate for examining the response of tree populations to climate change. This response function would enable us to determine the potential climatic optima for each population. Thus, H24 and S24 for individual populations were separately regressed on individual climate variables at the test site as follows:

$$
y_{i}=b_{0}+b_{1} x_{i}+b_{2} x_{i}^{2}+e
$$

where $y_{i}$ is the population mean at the ith site, $x_{i}$ is MAT, TCM, NDD, TWM, GDD, CI, MAP or AMI at the ith site, $b_{0}, b_{1}$ and $b_{2}$ are regression coefficients and $e$ is the residual. The potential optimum climate for each population on individual climate variables was calculated as the climate corresponding to maximum S24 or H24 on the response function.
Although polynomial regressions have limited accuracy in predicting responses beyond the range of climate covered by field trials, they allow us to cautiously examine the potential effects of climate change on forest productivity (see REHFELDT et al., 2001, 2002; ANDALO et al., 2005; Schmidtling, 1994). In the present study, the fitted response functions were used to predict S24 and H24 for trees planted and growing in the climate expected for the 2030-2039 period. Climate predicted for the 2030-2039 period were either within the range of the tested climate for some sites or slightly beyond the range for others.

The impact of climate change was calculated as a percentage difference between performances (S24 and H24) in the 1961-1990 and in the future climate as described below:

$$
\Delta_{x}=\frac{y_{x}-y_{00}}{y_{00}} \times 100
$$

where $x$ is future climate, $\Delta_{x}$ is percentage change in H24 or S24 for trees planted and growing to age 24 years in the future climate, $y_{x}$ is H24 or S24 for trees planted and growing to age 24 years in the future climate, and $y_{00}$ is $\mathrm{H} 24$ or $\mathrm{S} 24$ for trees planted and growing in the 1961-1990 baseline climate.

We will show later that, a balance between MAP and GDD at the test site largely influenced growth and survival. During this century, the Alberta climate is expected to warm substantially. For example, by the 2030-2039 period, MAT and TCM could, respectively, increase by an average of $2{ }^{\circ} \mathrm{C}$ and $3.2^{\circ} \mathrm{C}$ over the 1961-1990 climate. During the same period, GDD, MAP and AMI could increase by an average of $342(28 \%)$, $20 \mathrm{~mm}(4.1 \%)$ and $0.6(22.2 \%)$, respectively (ALBERTA ENVIRONMENT, 2005, 2004). This shows that in a changing climate, winters could become warmer posing only a minimum risk to tree survival. On the contrary, a disproportional increase in GDD and MAP means that growing seasons could become increasingly warmer and drier, causing tree mortality in young stands and lower annual growth for both young and old stands. Therefore, AMI was considered the most appropriate variable for predicting S24 and H24 in the future Alberta climate. Thus, future predictions of survival and growth were limited to AMI response functions.

\section{Results and Discussion}

\section{Genetic Variability}

Table 2 summarises mean growth and survival, and the levels of genetic variation for H24 and D24. Survival was moderate at sites B (55.2\%) and C (54.4\%) and high $(75.2-96.4 \%)$ at all other sites. Significant $(P \leq 0.05)$ variation among populations for $\mathrm{S} 24$ existed only at site $\mathrm{D}$ and $\mathrm{J}$ where the between-population genetic variance was $16.1 \%$ and $23.5 \%$ of the between-population phenotypic variance. Generally, S24 was not significantly $(P>0.05)$ related to geography and climate of seed origin.

Variation among populations for H24 and D24 was significant $(P \leq 0.05)$ on individual and across-sites 
Table 2. - General means with standard errors and range of population means for growth and survival, and levels of population variation for height and diameter growth

\begin{tabular}{|c|c|c|c|c|c|c|c|c|}
\hline \multirow[t]{2}{*}{ Site } & \multicolumn{3}{|c|}{$\overline{\mathrm{H} 24(\mathrm{~m})}$} & \multicolumn{3}{|c|}{$\mathrm{D} 24(\mathrm{~cm})$} & \multicolumn{2}{|c|}{ S24 (\%) } \\
\hline & Mean & Range & $\rho$ & Mean & Range & $\rho$ & $\overline{\text { Mean }}$ & Range \\
\hline$\overline{\mathrm{B}}$ & $4.69 \pm 0.11$ & $3.67-5.21$ & $0.130^{* *}$ & $6.57 \pm 0.19$ & $5.02-7.42$ & $0.117^{* * *}$ & $55.2 \pm 1.6$ & $31.1-84.4$ \\
\hline $\mathrm{C}$ & $3.85 \pm 0.25$ & $3.27-4.36$ & $0.089 * *$ & $5.81 \pm 0.50$ & $4.94-7.10$ & $0.073^{*}$ & $54.4 \pm 3.2$ & $40.0-75.6$ \\
\hline $\mathrm{D}$ & $6.58 \pm 0.16$ & $5.52-7.71$ & $0.174 * * *$ & $10.69 \pm 0.24$ & $9.80-11.41$ & 0.043 & $82.9 \pm 3.5$ & $55.6-97.8$ \\
\hline $\mathrm{E}$ & $6.59 \pm 0.13$ & $5.38-7.20$ & $0.179 * * *$ & $10.34 \pm 0.24$ & $9.05-11.13$ & $0.091 * * *$ & $96.4 \pm 0.8$ & $88.9-100$ \\
\hline $\mathrm{F}$ & $5.04 \pm 0.20$ & $4.15-5.70$ & $0.118^{* * *}$ & $8.13 \pm 0.36$ & $6.62-9.49$ & $0.098 * * *$ & $75.2 \pm 4.0$ & $64.4-93.3$ \\
\hline G & $6.31 \pm 0.24$ & $5.40-6.78$ & $0.100 * * *$ & $8.78 \pm 0.38$ & $7.21-9.30$ & $0.067 * * *$ & $85.0 \pm 2.5$ & $71.1-97.8$ \\
\hline $\mathrm{H}$ & $5.62 \pm 0.15$ & $4.28-6.48$ & $0.209 * * *$ & $8.87 \pm 0.23$ & $6.80-10.08$ & $0.153^{* * *}$ & $95.7 \pm 1.0$ & $82.2-100$ \\
\hline J & $6.50 \pm 0.19$ & $4.46-7.15$ & $0.211 * * *$ & $9.72 \pm 0.39$ & $6.11-10.58$ & $0.134 * * *$ & $89.0 \pm 2.3$ & $46.7-100$ \\
\hline $\mathrm{AC}$ & $5.57 \pm 0.38$ & $4.84-5.99$ & $0.106^{* *}$ & $8.52 \pm 0.65$ & $7.19-9.18$ & $0.066^{* *}$ & $71.0 \pm 10.3$ & $58.7-77.4$ \\
\hline
\end{tabular}

AC - Across sites; $\rho\left(\rho_{s s}\right.$ or $\left.\rho_{a c}\right)$ - population variance as a fraction of the phenotypic variance (intraclass correlation); * $-\mathrm{P} \leq 0.05 ; * *-\mathrm{P} \leq 0.01$; *** $-\mathrm{P} \leq 0.001 ; \mathrm{H} 24, \mathrm{D} 24, \mathrm{~S} 24$ - height, dbh and survival at 24 years; other codes see Table 1.

Table 3. - Correlations among climate variables at the population origin and PCA analysis examining the climatic grouping of white spruce populations in Alberta.

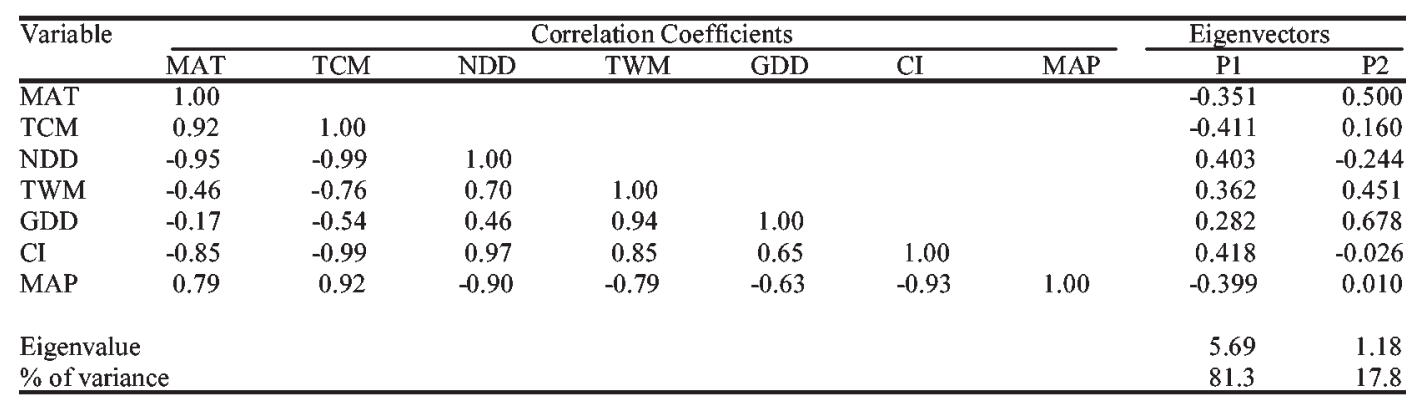

P1 and P2 - first and second principal components; other codes see Table 1.

(Table 2). On individual sites, the between-population genetic variance was $8.9-21.1 \%(\mathrm{H} 24)$ and $4.3-15.3 \%$ (D24) of the between-population phenotypic variance. When the population $x$ site interaction was removed by the combined-site analysis, the between-population genetic variance was $10.6 \%(\mathrm{H} 24)$ and $6.6 \%$ (D24) of the between-population phenotypic variance. Comparable estimates of genetic variation among white spruce populations are from nursery experiments and young field provenance trials in the eastern part of the species' natural range (see LI et al., 1993; LI et al., 1997; LESSER and PARKER, 2004). Because of large age differences, the amount of genetic variability observed in the present Alberta study may not be directly compared with that observed in previous studies elsewhere. However, given the older age of the Alberta study, white spruce may be more genetically variable in the western than eastern part of its natural range.

In the present study, we assumed that populations from the hybrid zone between white and Engelmann spruce were white spruce. If any of these populations were hybrids with different growth potential from that of white spruce populations in the region, the level of genetic variation observed in the present study may be slightly inflated.

Because the PCA had similar results for most sites, only results from a combined-site analysis with 21 populations are discussed. Table 3 shows that the first (P1) and second (P2) principal component accounted for $81.3 \%$ and $17.8 \%$ of the variance in the data, respectively. P1 had similar loading for all variables, whereas P2 had high loading for GDD. A plot of P1 and P2 shows that based on climate, Alberta white spruce could be divided into southern, central and northern regions (Figure 2). This grouping is clearly demonstrated along the $\mathrm{P} 1$ axis. In terms of climate, these three regions represent the cold, dry and highly continental region

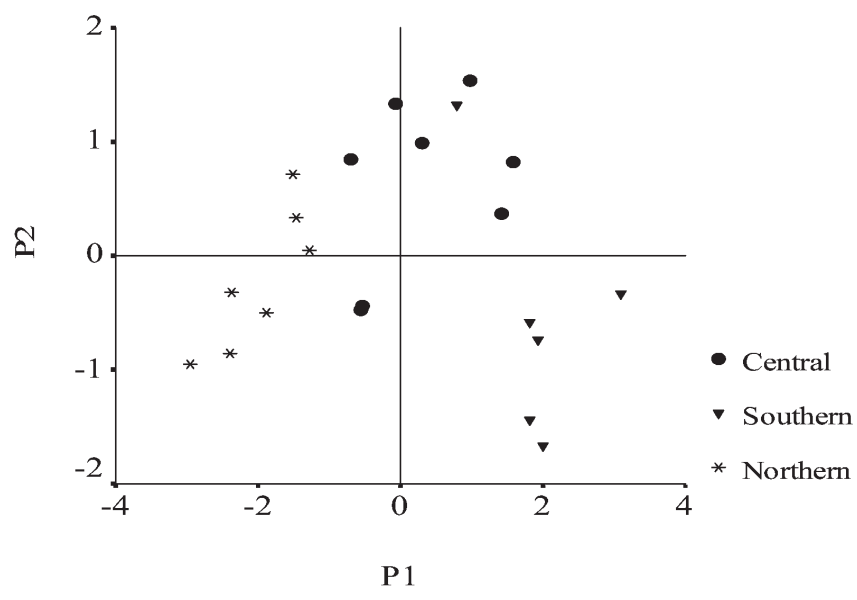

Figure 2. - Plot of the first (P1) and second (P2) principal components illustrating the division of Alberta into three white spruce climatic regions. 
Table 4. - Pearson's correlations for population means between biological variables and climate of population origins.

\begin{tabular}{llllllllll}
\hline Region & & MAT & TCM & NDD & TWM & GDD & CI & MAP & AMI \\
\hline Northern & H24 & $0.90^{* *}$ & $0.96^{* * *}$ & $-0.94^{* *}$ & -0.34 & 0.56 & $-0.94^{* *}$ & $0.90^{* *}$ & -0.75 \\
& D24 & $0.83^{*}$ & $0.92^{* *}$ & $-0.87^{*}$ & -0.43 & 0.46 & $-0.92^{* *}$ & $0.84^{*}$ & $-0.78^{*}$ \\
& S24 & -0.42 & -0.17 & 0.35 & -0.58 & -0.60 & 0.02 & -0.23 & -0.05 \\
\multirow{5}{*}{ Central } & H24 & 0.44 & 0.23 & -0.32 & 0.41 & 0.51 & -0.12 & 0.29 & 0.03 \\
& D24 & $0.74^{*}$ & 0.56 & -0.65 & 0.31 & 0.53 & -0.45 & 0.66 & 0.01 \\
& S24 & -0.69 & $-0.74^{*}$ & $0.77^{*}$ & 0.32 & 0.01 & $0.75^{*}$ & $-0.82^{*}$ & 0.46 \\
& & & & & & & & & \\
Southern & H24 & 0.23 & -0.68 & 0.35 & 0.53 & 0.58 & $0.85^{*}$ & -0.78 & 0.71 \\
& D24 & 0.12 & -0.78 & 0.49 & 0.47 & 0.52 & $0.87^{*}$ & $-0.87^{*}$ & 0.72 \\
& S24 & -0.04 & $-0.87^{*}$ & 0.64 & 0.35 & 0.40 & $0.83^{*}$ & $-0.88^{*}$ & 0.65 \\
\hline
\end{tabular}

$*-\mathrm{P} \leq 0.05 ; * *-\mathrm{P} \leq 0.01 ; * * *-\mathrm{P} \leq 0.001$; other codes see Table 1 and 2 .

(northern Alberta), the relatively moist and warm region at medium latitudes and elevations (central Alberta) and the moist, warm and less continental region at high elevations in the foothills and Rocky Mountains region (southwestern Alberta). Although the southern region has the highest precipitation and the least extreme temperatures, it has the lowest GDD and therefore the shortest growing season.

It should be noted that the existence of three climatic groups of white spruce populations is merely imposed by the Alberta topography and does not indicate the existence of white spruce ecotypes in Alberta. Within the three regions, variation for growth potential is strongly clinal in relation to climate of seed origin. Clines are the steepest in the northern and southern regions (Table 4). Growth potential was linearly related to winter temperatures (MAT, TCM, NDD), continentality (CI) and precipitation (MAP) at the place of seed origin. Similar clines were demonstrated for geographic variables in the eastern part of the species natural range (see KHALIL,
1986; Furnier et al., 1991; Nienstaedt and RiemenSCHNEIDER, 1985).

Table 4 also shows that for all three regions, growth potential was not related to summer temperatures (TWM and GDD). This suggests that cool season temperatures and moisture limitations are the major climatic factors controlling genetic differentiation of white spruce in Alberta.

\section{Population Response to Climatic Transfer}

Table 5 summarises $\mathrm{H} 24$ and S24 response functions for the eight climate variables, which shows that both growth and survival responded most to MAP and AMI. Table 5 also shows that cool season temperatures may have more control on survival than height growth. In terms of $\mathrm{R}^{2}$, the relationships of GDD with S24 and H24 appear to be relatively low. However, the joint effect of MAP, GDD and consequently AMI on survival and growth was apparent, especially when survival and growth at the two extreme sites (B and F) are consid-

Table 5. - Mean and range of $\mathrm{R}^{2}$ for population response functions and the predicted potential optimum climate for annual moisture index (AMI) based on the second order polynomial regression.

\begin{tabular}{|c|c|c|c|c|c|c|c|}
\hline \multirow[t]{2}{*}{ Variable } & \multirow[t]{2}{*}{$\bar{R}^{2}$} & \multirow[t]{2}{*}{$\mathrm{R}^{2}$ Range } & \multirow[t]{2}{*}{$\mathrm{SN}$} & \multicolumn{4}{|c|}{ Predicted Average Optimum AMI } \\
\hline & & & & Region & $\mathrm{X}_{\mathrm{I}}$ & $\mathrm{X}_{\mathrm{op}}$ & $\Delta(\%)$ \\
\hline Survival (S24) & & & & Survival (S24) & & & \\
\hline MAT & 0.37 & $0.06-0.78$ & 1 & Northern & 3.1 & 2.2 & $-29.0 * * *$ \\
\hline $\mathrm{TCM}$ & 0.45 & $0.07-0.84$ & 2 & Central & 2.3 & 2.2 & -4.3 \\
\hline NDD & 0.47 & $0.08-0.87$ & 3 & Southem & 1.6 & 2.1 & $+31.3^{*}$ \\
\hline TWM & 0.33 & $0.06-0.91$ & 2 & & & & \\
\hline GDD & 0.41 & $0.03-0.95$ & 2 & & & & \\
\hline $\mathrm{CI}$ & 0.52 & $0.07-0.91$ & 3 & & & & \\
\hline MAP & 0.65 & $0.19-0.92$ & 8 & & & & \\
\hline AMI & 0.61 & $0.23-0.87$ & 4 & & & & \\
\hline Height (H24) & & & & Height (H24) & & & \\
\hline MAT & 0.31 & $0.00-0.64$ & 0 & Northern & 3.1 & 2.2 & $-29.0 * * *$ \\
\hline $\mathrm{TCM}$ & 0.33 & $0.01-0.60$ & 0 & Central & 2.3 & 2.1 & -8.7 \\
\hline NDD & 0.37 & $0.03-0.63$ & 0 & Southem & 1.6 & 2.1 & $+31.3^{*}$ \\
\hline TWM & 0.33 & $0.04-0.88$ & 1 & & & & \\
\hline $\mathrm{CI}$ & 0.42 & $0.04-0.70$ & 0 & & & & \\
\hline GDD & 0.37 & $0.04-0.80$ & 0 & & & & \\
\hline MAP & 0.61 & $0.29-0.90$ & 7 & & & & \\
\hline AMI & 0.71 & $0.40-0.93$ & 9 & & & & \\
\hline
\end{tabular}

$\mathrm{SN}$ - number of significant regressions $\mathrm{P} \leq 0.05) ; \mathrm{R}^{2}$ - coefficient of determination; $\mathrm{X}_{\mathrm{I}}$ - inhabited climate; $\mathrm{X}_{\mathrm{op}}$ - predicted optimum climate; $\Delta(\%)$ - difference between $\mathrm{X}_{\mathrm{I}}$ and $\mathrm{X}_{\mathrm{op}}$ expressed as percentage of $\mathrm{X}_{\mathrm{I}}$; $*-\mathrm{P} \leq 0.05 ; * * *-\mathrm{P} \leq 0.001 ; \bar{R}^{2}$ - average coefficient of determination; other codes see Table 1. 
ered. At site B where GDD is high, low MAP limited growth, whereas at a high elevation site $\mathrm{F}$ where MAP is high, growth was limited by low GDD.

Figures 3 and 4 illustrate the response of H24 and S24 to AMI for three populations selected from three distinct regions. Site B and F are at the upper and lower end of the response functions, respectively. Using all 21 popu- lations, it was determined that the average potential optimum AMI for H24 and S24 was 2.2 compared with the average inhabited AMI of 2.4. Thus, on average, the tested white spruce requires $8.3 \%$ moister environment than its current environment, although large differences exist among regions (Table 5). These results show that populations in northern Alberta (highly continental and

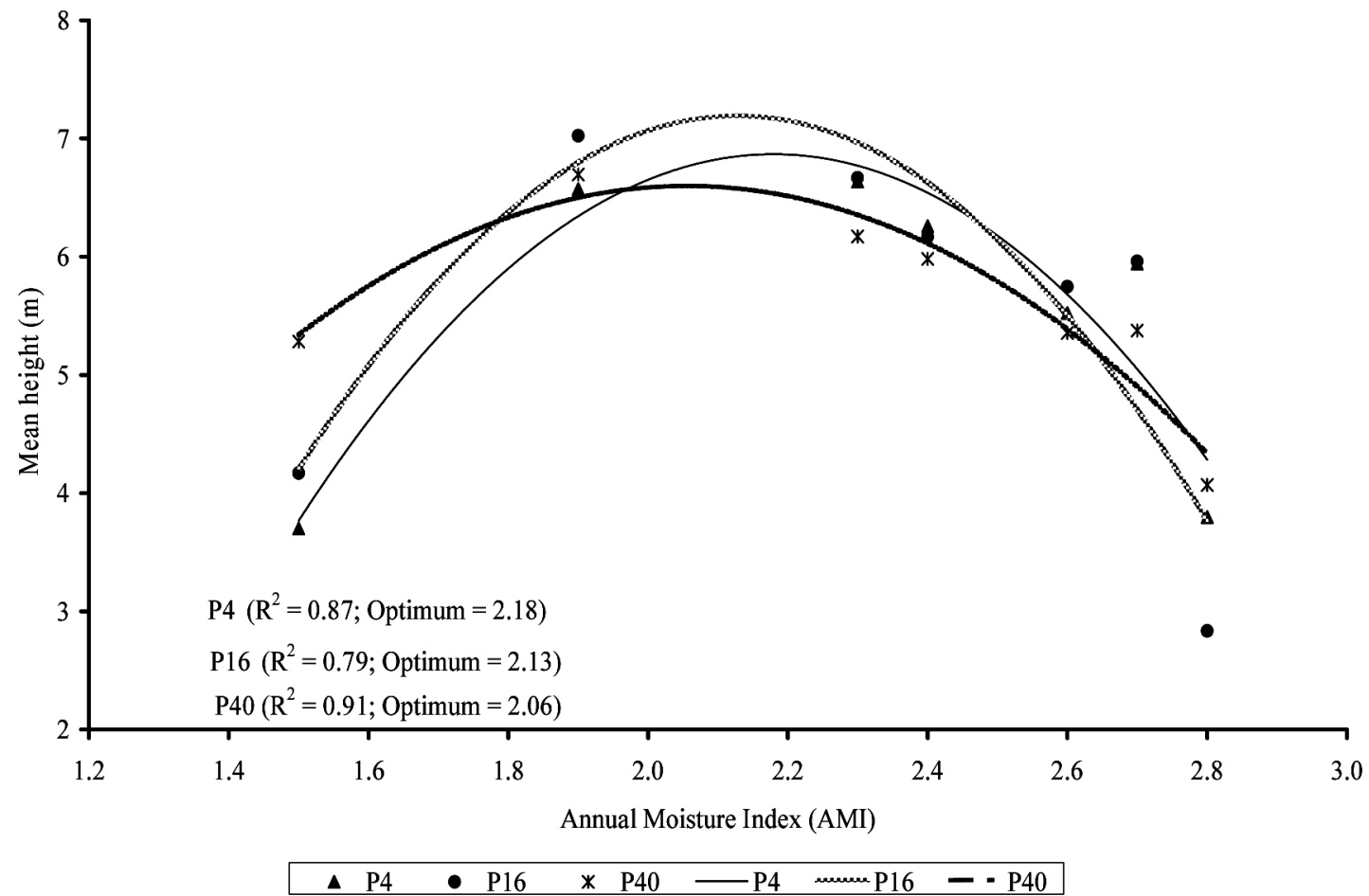

Figure 3. - Height response functions for a northern (P4), central (P16) and southern (P40) population and the predicted optimum AMI.

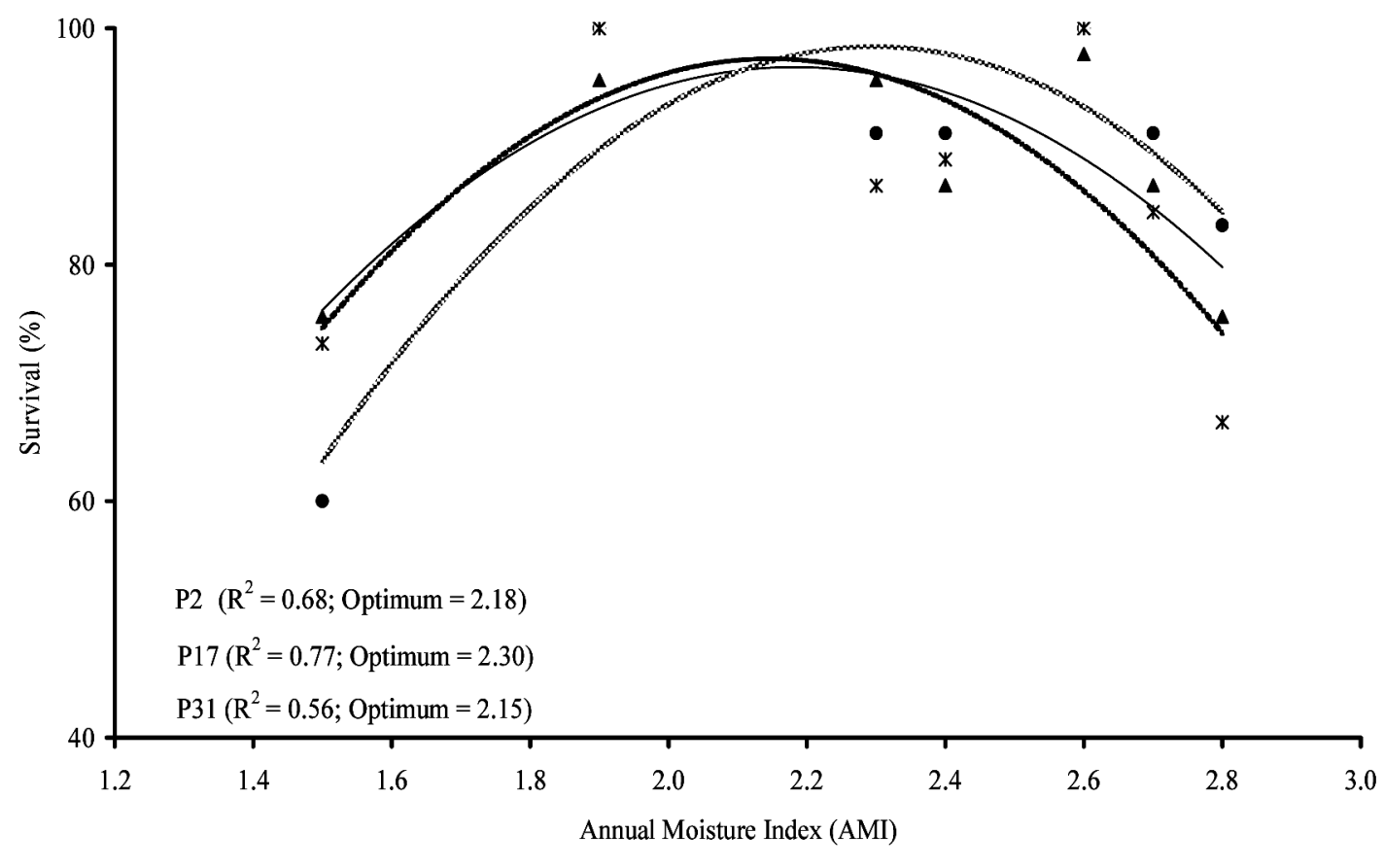

\P2 • P17 * P31 - P2 нияе P17 - - P31

Figure 4. - Survival response function for a northern (P2), central (P17) and southern (P31) population and the predicted optimum AMI. 
dry) and those in the foothills and Rocky Mountains (less continental and low GDD) inhabits less than optimal climate compared to those in central Alberta (warm and moist).

The pattern of population response to climatic transfer observed in the present study is similar to that observed in lodgepole pine in British Columbia (REHFELDT et al.; 1999, 2001) and Scotch pine from Russia (REHFELDT et al., 2002). In both species, populations from high latitudes and other climatically marginal environments were far from their optimum climate with respect to MAT (REHFELDT et al., 1999, 2001), GDD and degree of continentality (REHFELDT et al., 2002) compared to those from low latitudes, low elevation and other climatically mild environments. In white ash (Fraxinus americana L.), RoBERDs et al. (1990) showed that populations from northern latitudes attained optimum height when moved $5^{\circ}$ south of their origin, southern latitude populations reached optimum height $1.5^{\circ}$ north of their origin and populations from the centre of the species' distribution reached optimum height in their native environments. Earlier, MATYAS and YeATMAN (1992) showed the same for jack pine.

The present study also showed that for white spruce in Alberta, the AMI climate for optimum survival and height growth were the same. This is somehow contrary to lodgepole pine in British Columbia where REHFELDT et al. (1999) found that optimum growth required a more continental climate than optimum survival.

\section{Potential Effects of Climate Change}

In the present study, we used the response functions developed for the 1961-1990 AMI climate to predict H24 and S24 in a future climate scenario. The results are summarised in Table 6. They show that, as early as 2030-2039, warming could cause serious decline in survival and growth of white spruce in Alberta. Warming could intensify drought in northern and central Alberta making it difficult for white spruce to attain substantial survival and growth. At higher elevations in the foothills and Rocky Mountains region, warming could either have less negative effects or promote survival and growth. For example, at site E (990 metres above sea level), the decline in S24 and H24 would only be $2.6 \%$ and $4.7 \%$, respectively. At much higher elevations such as site $\mathrm{F}$ (1220 metres above sea level), S24 and H24 could increase by an average of $27.6 \%$ and $57.7 \%$, respectively.
Because populations from different climatic regions of Alberta exhibited different AMI optima, we found regional differences in the effect of climate change on survival and growth. Table 6 shows that except for site $\mathrm{E}$, the decline in S24 and H24 could be the greatest among populations originating from central Alberta, which currently have near optimal AMI. These populations may not be drought-hardy to survive and grow adequately in the predicted future climate. Similar inferences were made by REHFELDT et al. (2001, 2002) who predicted that lodgepole pine and Scotch pine populations inhabiting near optimal climates would be the most affected by climate change.

In the present climate, growth and survival at higher elevations is constrained by low degree days not drought. Consistently, REHFELDT et al. (1999, 2001, 2002) argued that warming at high elevations would drive moisture indices toward their optimal values and therefore increase forest productivity. The predicted drastic increase in $\mathrm{S} 24$ and $\mathrm{H} 24$ at site $\mathrm{F}$ attests this. It has also been argued that as warming progresses, cool regions at high latitudes and elevations could become favourable to populations from low latitudes and elevations, respectively (PERSSON, 1998). REHFELDT et al. $(1999,2001,2002)$ showed that in the future warmer climate, populations from low latitudes could be the best in growth at high latitudes. Likewise, populations from low elevations could be the best at higher elevations. Table 6 shows that at site F, warming could favour populations from relatively drier regions of central and northern Alberta than local ones. Therefore, the present study confirms that warming at higher elevation regions could increase productivity due to improved growing conditions for local populations or through transfer of populations from low elevation areas.

Caution should be taken in assimilating the predictions of changes in growth and survival of white spruce in Alberta due to climate change. Although there are agreements in predictions of future temperatures, many general circulation models (GCM) differ greatly in prediction of future precipitation (LOEHLE and LEBRANC, 1996) and long-term predictions exhibit the highest uncertainties (see BARROW and YU, 2005). In addition, predictions of $\mathrm{H} 24$ and $\mathrm{S} 24$ for future climate were derived by extrapolating the existing response functions beyond the existing white spruce test site AMI climate.

Although the predicted declines in growth and survival of white spruce due to climate change are large,

Table 6. - Mean S24 and H24 for all populations and for populations from three regions as predicted by the response functions for current (1961-1990) and future (2030-2039) AMI climates.

\begin{tabular}{|c|c|c|c|c|c|c|c|c|c|c|c|c|}
\hline \multirow[t]{2}{*}{$\overline{\text { Site }}$} & \multicolumn{2}{|c|}{ Mean S24 (\%) } & \multicolumn{4}{|c|}{ Percentage Change in S24 } & \multicolumn{2}{|c|}{ Mean H24 (m) } & \multicolumn{4}{|c|}{ Percentage Change in $\mathrm{H} 24$} \\
\hline & $\overline{\mathrm{P}_{00}}$ & $\overline{P_{30}}$ & Mean & NT & $\mathrm{CT}$ & ST & $\overline{\mathrm{P}_{00}}$ & $\mathrm{P}_{30}$ & Mean & NT & CT & $\overline{\text { ST }}$ \\
\hline$\overline{\mathrm{B}}$ & 75.2 & 9.8 & -88.5 & -82.3 & -94.7 & -86.4 & 4.14 & 0.00 & -100 & -100 & -100 & -100 \\
\hline D & 93.7 & 61.7 & -34.2 & -31.6 & -38.5 & -31.5 & 6.13 & 2.56 & -58.1 & -49.4 & -66.5 & -57.0 \\
\hline E & 93.4 & 90.8 & -2.6 & -1.3 & -2.7 & -4.0 & 6.10 & 5.80 & -4.7 & -0.6 & -6.3 & -7.4 \\
\hline $\bar{F}$ & 75.7 & 96.0 & +27.6 & +28.5 & +31.5 & +20.7 & 4.12 & 6.44 & +57.7 & +60.8 & +65.7 & +43.6 \\
\hline G & 82.1 & 33.2 & -61.4 & -57.5 & -69.1 & -55.6 & 4.83 & 0.36 & -93.1 & -87.8 & -97.7 & -93.1 \\
\hline $\mathrm{H}$ & 87.0 & 33.2 & -62.9 & -59.1 & -70.4 & -57.1 & 5.37 & 0.36 & -93.6 & -88.6 & -97.9 & -93.6 \\
\hline $\mathrm{J}$ & 95.4 & 61.7 & -35.2 & -32.4 & -39.6 & -32.7 & 6.34 & 2.56 & -59.4 & -50.6 & -67.7 & -58.4 \\
\hline
\end{tabular}

$\mathrm{P}_{00}$ and $\mathrm{P}_{30}-1961-1990$ and 2030-2039 periods, respectively; NT, CT and ST - northern, central and southern regions, respectively; other codes see Table 1. 
they are consistent with the present natural distribution of the species in Alberta. From the Alberta Climate Model (Alberta Environment, 2005), the Northern Fescue Plains seed zone (ASRD, 2005) immediately south of the limit of the white spruce distribution in Alberta has an average AMI of 3.9. This moisture index is close to the AMI of 3.7 predicted for site B in northern Alberta for the 2030-2039 period. At this AMI, site B is predicted to have an average S24 of $9.8 \%$ and may not sustain meaningful height growth (Table 6). Table 1 shows that the populations tested in this trial originated from locations with the AMI of 1.2-3.5. Therefore, the upper threshold of AMI for white spruce in Alberta could be in the range between 3.5 and 4.0.

\section{Conclusions}

Provenance trials are essential for matching tree populations to planting sites to maximise production while safeguarding adaptation. Based on our analysis of the Alberta series of white spruce provenance trials, we have concluded that: (1) The level of genetic variation in growth potential among white spruce populations is moderate but slightly higher than that observed in other areas of North America. (2) The pattern of variation is clinal whereby growth potential declines from central Alberta northward in response to a decrease in winter temperatures and precipitation, and an increase in continentality of seed origin. (3) Although many climate variables may have a role in determining survival, a balance between GDD and MAP had the strongest effect on both survival and height growth on Alberta test sites. Therefore, AMI provided a simple measure of drought potential, which was used to describe survival and growth of white spruce in Alberta in the present climate and predict the impact of climate change on forest productivity in the future. Using AMI, we determined that populations at the cold and dry areas of northern Alberta and those at high elevations in the foothills and Rocky Mountain regions inhabit climates with significantly different AMI than their potential optimum climate. Populations at mid-latitudes and elevation in central Alberta are close to their optimum AMI. (4) The predicted changes in Alberta climate would seriously reduce survival and growth of white spruce in central and northern Alberta. Because of the precipitation pattern, northern and central Alberta would become increasingly dry making it difficult for white spruce to attain significant survival and growth. On the contrary, survival and growth would increase in the Upper Foothills and Rocky Mountains regions in southwestern Alberta as warming extends the growing season, increases GDD and boosts AMI toward optimal values.

\section{Acknowledgements}

We thank TAmmy DeCosta, NATHAN ANTONIUK and JohN QUINN for technical support, field measurements and data management, TAMMY KoBLIUK for valuable assistance with climate data, and Dr. CSABA MATYAS and an anonymous reviewer for critically reviewing the manuscript and suggesting areas for improvement. Alberta Environment, Alberta Sustainable Resource Development, Manning Forestry Research Fund and the Natural Sciences and
Engineering Research Council of Canada funded this research.

\section{References}

Achuff, P. L. and G. H. Laroi (1977): Picea-Abies forests in the highlands of Northern Alberta. Vegetatio 33: 127-146.

AFLW (Alberta Forestry, Lands and Wildlife) (1985): Alberta phase 3 forest inventory: An overview. ENR Report No. I/86. Edmonton.

AlBerta EnVIRONMENT (2004): Using the Alberta Climate Model to estimate future climates of Alberta. Unpublished Report. Alberta Environment/Sustainable Resource Development. Edmonton.

AlBerTa EnVIRONMENT (2005): Alberta Climate Model (ACM) to provide climate estimates (1961-1990) for any location in Alberta from its geographic coordinates. Publ. No. T/749. Alberta Environment. Edmonton.

Andalo, C., J. Beaulieu and J. Bousquet (2005): The impact of climate change on growth of local white spruce populations in Quebec, Canada. For. Ecol. Manage 205: 169-182.

ASRD (Alberta Sustainable Resource Development) (2005): Standards for tree improvement in Alberta. Alberta Lands and Forest Division. Publication Ref. No. T/079. Edmonton.

BARRow, E. and GE. Yu (2005): Climate scenarios for Alberta. A report prepared for the Prairie Adaptation Research Collaborative (PARC) in co-operation with Alberta Environment. Available at: http://www.parc.ca/ research_pub_scenarios.htm

Bongarten, B. C. and J. W. Hanover (1986): Provenance variation in blue spruce (Picea pungens) at eight locations in the United States and Canada. Silvae Genet. 35: $67-74$.

Funnier, G. R., M. Stine, C. A. Mohn and M. A. Clyde (1991): Geographic patterns of variation in allozymes and height growth in white spruce. Can. J. For. Res. 21: 707-712.

KHALIL, M. A. K. (1986): Variation in seed quality and juvenile characters of white spruce (Picea glauca (Moench) Voss). Silvae Genet. 35: 78-85.

KLEINSChMit, J. and J. C. BASTIEN (1992). IUFRO's role in Douglas-fir (Pseudotsuga menziesii (Mirb.) Franco.) tree improvement. Silvae Genet. 41: 161-173.

KozLOwsKI, T. T. (1999): Soil compaction and growth of woody plants. Scand. J. For. Res. 14: 596-619.

KRUTZSCH, P. (1992): IUFRO's role in coniferous tree improvement: Norway spruce (Picea abies (L.) Karst). Silvae Genet. 41: 143-150.

LANGLET, O. (1959): A cline or not a cline - a question of Scots pine. Silvae Genet. 8: 13-22.

LaroI, G. H. and J. R. Dugle (1968): A systematic and genecological study of Picea glauca and P. engelmannii, using paper chromatograms of needle extracts. Can. J. Bot. 46: 649-687.

LESSER, M. R. and W. H. PARKER (2004): Genetic variation in Picea glauca for growth and phonological traits from provenance tests in Ontario. Silvae Genet. 53: 141-148.

Li, P., J. Beaulieu and J. Bousquet (1997): Genetic structure and patterns of genetic variation among populations in eastern white spruce (Picea glauca). Can. J. For. Res. 27: 189-198.

Li, P., J. Beaulieu, A. Corriveau and J. Bousquet (1993): Genetic variation in juvenile growth and phenology in a white spruce provenance-progeny test. Silvae Genet. 42: 52-60. 
LOEHLe, C. and D. LeBranC (1996): Model-based assessment of climate change effect on forests: a critical review. Ecol. Model. 90: 1-31.

MATYAS, Cs. (1994): Modelling climate change effect with provenance test data. Plant Physiol. 14: 797-804.

MATYAS, Cs. (1996): Climatic adaptation of trees: rediscovering provenance tests. Euphytica 92: 45-54.

MATYAS, Cs. and C. W. YEATMAN (1992): Effect of geographical transfer on growth and survival of jack pine (Pinus banksiana Lamb.) populations. Silvae Genet. 41: 370-376.

Nienstaedt, H. and D. E. Riemenschneider (1985): Changes in heritability estimates with age and site in white spruce, Picea glauca (Moench) Voss. Silvae Genet. 34: 34-41.

Nienstaedt, H. and J. C. Zasada (1990): Picea glauca (Moench) Voss: White spruce, pp. 389-442. In: Silvics of North America: Vol. 1: Conifers, edited by R. M. BuRns and B. H. HonkAlA, Agricultural Handbook 654, USDA Forest Service. Washington, DC.

OGilvie, R. T. and E. von Rudloff (1968): Chemosystematic studies in the genus Picea (Pinaceae) IV. The introgression of white spruce and Engelmann spruce as found along the Bow River. Can. J. Bot. 46: 901-908.

Persson, B. (1998): Will climate change affect the optimum choice of Pinus sylvestris provenances? Silva Fen. 32: 121-128.

RAJORA, O. P. and B. P. DANCIK (2000): Population genetic variation, structure, and evolution in Engelmann spruce, white spruce and their natural hybrid complex in Alberta. Can. J. Bot. 78: 768-780.
REHFELDT, G. E. (1989): Ecological adaptations in Douglas-fir (Pseudotsuga menziesii var. glauca): a synthesis. For. Ecol. Manage. 28: 203-215.

Rehfeldt, G. E., C. C. Ying, D. L. Spittlehouse and D. A. Hamilton (1999): Genetic response to climate in Pinus contorta: Niche breadth, climate change and reforestation. Ecolog. Monogr. 69: 375-407.

Rehfeldt, G. E., W. R. Wykoff and C. C. Ying (2001): Physiologic plasticity, evolution, and impacts of a changing climate on Pinus contorta. Climatic Change 50: 355-376.

Rehfeldt, G. E., N. M. Tchebakova, Y. I. Parfenova, W. R. Wykoff, N. A. Kuzmina and L. I. Milyutin (2002): Intraspecific responses to climate change in Pinus sylvestris. Global Change Biology 8: 912-929.

RoBerds, J. H., O. J. HyUn and G. NAMKOONG (1990): Height response functions for white ash provenances grown at different latitudes. Silvae Genet. 39: 121-129.

RUdOlPH, T. D. and C. W. YEATMAN (1982): Genetics of jack pine. USDA Res. Pap. WO-38. Washington, DC.

SAS InstituTE (2004): SAS System for windows. Version 9.1. Carry, NC.

SchmidTLing, R. C. (1994): Use of provenance tests to predict response to climatic change: loblolly pine and Norway spruce. Tree Physiol. 14: 805-817.

StETTLER, R. F. and H. D. BRADShaW (1994): The choice of genetic materials for mechanistic studies of adaptation in forest trees. Tree Physiol. 14: 781-796.

XIE, C.-Y. and C. C. YING (1995): Genetic architecture and adaptive landscape of interior lodgepole pine (Pinus contorta ssp. latifolia) in Canada. Can. J. For. Res. 25: 2010-2021.

\title{
Gene Flow Between Introduced and Native Eucalyptus Species: Morphological Analysis of Tri-Species and Backcross Hybrids Involving $E$. nitens
}

\author{
By R. C. Barbour ${ }^{*}$, B. M. Potts and R. E. Vaillancourt \\ School of Plant Science and Cooperative Research Centre for Forestry, University of Tasmania, \\ Private Bag 55, Hobart 7001, Tasmania, Australia
}

(Received 10 ${ }^{\text {th }}$ March 2006)

\begin{abstract}
Summary
Morphometric analyses were conducted on secondgeneration tri-species and backcross hybrids in Eucalyptus. These hybrids were all produced using pollen from two $E$. nitens x cordata $\mathrm{F}_{1}$ hybrids and controlled pollination techniques. Tri-species hybrids were created with $E$. gunnii, E. ovata and E. viminalis as females, while backcrosses were produced with $E$. cordata. Multivari-

\footnotetext{
*) Corresponding author: Telephone: (03) 62262603, Fax: (03) 62262698. Telephone (int): +61 (3) 62262603, Fax: (int) +61

(3) 62262698. E-mail: rbarbour@utas.edu.au
}

ate analysis of seedling characteristics indicated that eighty percent of the backcross hybrids fell within the morphological range of $E$. cordata. All three cross combinations of the tri-species hybrids were biased away from $E$. nitens and towards their maternal parent and $E$. cordata. The inclusion of data for first-generation $\left(\mathrm{F}_{1}\right)$ hybrids between the pure parental species in the current work showed the $\mathrm{F}_{1}$ 's to be easily distinguishable from pure species, compared to second-generation hybrids. The use of morphology for detecting secondgeneration hybridisation involving exotic plantation species and native eucalypt populations will therefore be 